\title{
Rajeev S. Patke, Modernist Literature and Postcolonial Studies
}

Jaine Chemmachery

\section{(2) OpenEdition \\ 1 Journals}

Electronic version

URL: https://journals.openedition.org/ces/5729

DOI: $10.4000 /$ ces.5729

ISSN: 2534-6695

Publisher

SEPC (Société d'études des pays du Commonwealth)

\section{Printed version}

Date of publication: 1 September 2014

Number of pages: 111-112

ISSN: 2270-0633

\section{Electronic reference}

Jaine Chemmachery, "Rajeev S. Patke, Modernist Literature and Postcolonial Studies", Commonwealth Essays and Studies [Online], 37.1 | 2014, Online since 14 April 2021, connection on 18 July 2021. URL: http://journals.openedition.org/ces/5729 ; DOI: https://doi.org/10.4000/ces.5729

This text was automatically generated on 18 July 2021.

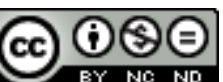

Commonwealth Essays and Studies is licensed under a Licence Creative Commons Attribution - Pas d'Utilisation Commerciale - Pas de Modification 4.0 International. 


\title{
Rajeev S. Patke, Modernist Literature and Postcolonial Studies
}

\author{
Jaine Chemmachery
}

\section{REFERENCES}

Rajeev S. Patke. Modernist Literature and Postcolonial Studies. Edinburgh: Edinburgh University Press, 2013. 224 p. ISBN (hb) 9780748639922. £70

Modernist Literature and Postcolonial Studies is an insightful analysis of the relation between modernity and colonialism, and between modernism and Postcolonial Studies. It is divided into three chapters dealing respectively with the relations between the modern, modernity and modernism; the debates between colonialism and modernism; and three case studies - a comparison between Rhys and Woolf, a reflection on the allegory in Kafka, a comparison between Nick Joaquin and Arun Kolatkar. The book also contains a pedagogical outline and a well-informed timeline covering 200 years, which immediately brings to light the powerful coincidences - sometimes the distortions between history and cultural productions (cf. the temporal collusion between the publication of Conrad's Heart of Darkness and the official revelations about the exactions committed by the Belgian colonial power). The 16-page-long timeline ends with a reference to Said's Culture and Imperialism which underlines the critical relevance of Patke's approach in his book. Notes follow each of the chapters while the book ends on a 14-page-long bibliography and a useful index.

2 Patke's main contention is that the histories of modernism and colonialism are intertwined and that modernist practices from Europe and the United States inspired adaptations among writers from the former colonies. In his introduction, Patke complains that the "modern" is too seldom read in conjunction with the "colonial" although the terms have a long common history. He then proceeds to distinguish between modernity, modernisation and modernism and raises theoretical questions about the time of modernism - "Is 'modernity' a project still ongoing? Is 'modernism' 
over and done with?" (xxv) - and the temporality/-ies of modernity. By quoting Carlos Fuentes ("the clocks of all men and women, of all civilisations, are not set at the same hour," 1988: 199), Patke, for instance, hints at François Herzog's concept of "regimes of historicity."

In the first chapter, Patke traces the genealogy of the term "modern," referring successively to Baudelaire's literary concept of the "modern," to Dipesh Chakrabarty's spatial and temporal assumption of it, to Jameson's proposition on modernity, before quoting the debate between Anderson and Berman. The delineation of modernity is operated subtly as Patke never treats the latter as a monolith but always unfolds the strata shaped by previous discourses on modernity. He also explores the various stages of modernity - 1492, the Quarrel between the Ancients and the Moderns, the industrial age, the expansion of capitalism in conjunction with colonialism - which has him conclude, with Foucault and Weber, that European modernity emerged less from an ideal of reason than through its instrumental use of combined capitalism and colonisation. So Patke takes us on a chronological and theoretical journey to reveal how European modernity relied on the fact that non-Europeans should never be modern in the same way (11).

4 Patke similarly distinguishes between "colonialism," "imperialism," and neocolonialism. Only then does he present modernism as both an effect born with modernity and a reaction to it. But against the myth of an Anglo-American modernity and the pluralising of "modernity," Patke calls for "a rethinking of how modernism is 'transculturated' within the postcolonial context" (28) using the term "postcolonial" to refer to "the continuing effects of colonial habits and institutions on cultural orientations and economic as well as political practices among groups no longer colonised" (15). He thus insists on the necessity to move away from monologic and Eurocentric accounts of modernism and gauge the transformation undergone by modernist ideas in works from the ex-colonies.

In the second chapter, Patke recalls theoretical debates about modernism. The first one, "modernist literature and the left," draws on discussions between Lukacs and Brecht on realism vs. expressionism, between Lukacs and Adorno on the representation of trauma, and between Fredric Jameson and Ahmad Aijaz on Third World texts. The second debate, "Modernist literature and the right," mainly recalls that modernist innovative poetics were often produced by such politically conservative authors as Pound or Yeats. The third one, "modernist literature and race," suggests that if some authors looked towards the colonies for rejuvenation, Conradian texts among others highlight the tensions underlying the modern and the colonial. As interesting as recalling these debates may be, it is less clear what Patke's intention is in this section. The conclusion of his analysis about Conrad and Salih, "literary modernism becomes a repertoire of strategies intent on coping with that which divides and corrupts" (89), sounds slightly plain compared to the theoretical questions and analyses provided earlier.

6 The last chapter, entitled "Case studies," is interesting as it conjures up literature. The relevance of the texts brought together for comparison is not to be questioned. Comparing The Voyage Out and Wide Sargasso Sea to discuss the issue of gender and modernism is pertinent. So is it to conjure up Kafka's writings to discuss the way allegory can be seen as articulating postcolonialism and modernism, or to link modernism and faith to question how modernist practices are alive in postcolonial 
fictions. Yet the tendency of Patke sometimes to paraphrase the texts and bring forward biographical details at the expense of deeper literary analyses may leave the readers unsatisfied. But this may be caused by the high number of literary and theoretical references present in the book which, one feels, are sometimes dealt with (too) quickly.

7 Nevertheless, this book is a must-read for anyone interested in the relation between modernity and colonialism, and in the links between colonial history, culture and postcolonial theory. The book is thought-provoking and admirable in its scope and depth. It certainly succeeds in drawing the reader's attention to the necessity of revisiting colonial history, modernist classics and postcolonial works through the lens of postcolonialism.

\section{AUTHORS}

\section{JAINE CHEMMACHERY}

Jaine CHEMMACHERY is an alumna of the Ecole Normale Supérieure Lyon and is currently teaching at the University of Paris 1 - Sorbonne. Her doctoral dissertation was on R. Kipling and S. Maugham's short stories on Empire and the relation between colonialism, modernity and the genre of the short story. 